\title{
MENGEMBANGKAN SIKAP KEDISPLINAN DAN KETERTIBAN DALAM PEMBELAJARAN DARING MELALUI MEDIA GAVI BERBASIS KONTEKSTUAL DI SEKOLAH DASAR
}

\author{
Wira Puspita \\ Guru SD Islam Al Azhar 21 Pontianak \\ Email: wirapuspita.150180@gmail.com
}

\begin{abstract}
Abstrak
Penulisan ini di latar belakangi oleh perasaan sedih penulis melihat prilaku siswa yang mulai berubah ketika mengikuti proses pembelajaran daring. Mulai dari ketidak displinan siswa dalam mengikuti proses pembelajaran daring, ketidakdiplinan dalam mengumpulkan tugas, kurangnya respon siswa selama proses pembelajaran dan menurunnya nilai hasil akhir semester I tahun pelajaran 2020/2021. Hal ini terjadi karena siswa sudah mulai merasa jenuh dan bosan dengan model pembelajaran daring. Dari permasalah tersebut, penulis memilih satu alternatif yang relevan guna mengembangkan kembali sikap kedisplinan dan ketertiban siswa dengan cara merancang sebuah proses pembelajaran yang menarik dengan menggunakan media pembelajaran yang memuat gambar dan video yang edukatif dan kontekstual. Dalam proses memecahkan masalah, penulis menggunakan beberapa langkah mulai dari menganalisis situasi, mewawancarai untuk mencari penyebab permasalahan, menentukan beberapa alternatif pemecahan masalah, merancang RPP yang memuat gambar dan video yang edukatif dan kontekstual, melaksanakan proses pembelajaran daring menggunakan media yang tercantum di RPP, melakukan observasi, merefleksi hingga akhirnya menindaklanjuti beberapa temuan. Hasil dari pemecahan masalah menunjukkan bahwa dengan menggunakan media pembelajaran yang memuat gambar dan video yang edukatif dan kontekstual mampu membuat siswa kembali bersemangat untuk mengikuti proses pembelajaran daring sehingga kedisplinan dan ketertiban siswa bisa kembali dikembangkan, seperti siswa bisa lebih awal hadir di pembelajaran daring, siswa menjadi aktif dalam merespon pertanyaan guru dan siswa merasa sangat senang sehingga rasa jenuh dan bosan yang mereka rasakan sebelumnya hilang. Pada akhirnya nanti yang diharapkan kedepannya siswa semakin disiplin dan tertib dalam menjalan aktivitas sehari-hari sehingga tujuan utama yaitu membentuk akhlatul karimah siswa Al Azhar akan terwujud.
\end{abstract}

\section{Kata Kunci : Ketertiban, Kontekstual, Media GAVI, Pembelajaran Daring, Sikap Kedisplinan}

\section{PENDAHULUAN}

Kondisi pandemi covid 19 saat ini memaksa proses kegiatan belajar mengajar harus beralih dari tatap muka menjadi daring. Di mana seluruh kegiatan pembelajaran harus dilakukan dengan cara jarak jauh dan seluruh penyampaian materi akan disampaikan dari rumah masing-masing. Sistem pembelajaran daring (dalam jaringan) merupakan sistem pembelajaran tatap muka secara langsung antara guru dan siswa tetapi dilakukan melalui media online yang menggunakan jaringan internet. Guru harus memastikan kegiatan belajar mengajar bisa tetap berjalan, meskipun siswa berada di rumah. Dan solusinya guru dituntut agar dapat mendesain media pembelajaran yang menarik yang mampu membuat siswa merasa pembelajaran daring bukanlah hal yang membosankan.

Di semester pertama di ajaran tahun 2020/2021, siswa kelas V Firdaus terlihat tidak aktif saat kegiatan pembelajaran daring, tidak disiplin dalam menghadiri pembelajaran daring, kurangnya antusias siswa dalam merespon pertanyaan dari guru dan kurangnya kemandirian mereka dalam mengerjakan tugas. Beberapa hal tersebut membuat penulis bertanya-tanya. Apakah siswa kelas V Firdaus sudah mulai merasakan kebosanan dan kejenuhan dalam pembelajaran daring ini?. Pertanyaan itu semakin menjadi saat pelaksanaan Penilaian Akhir Semester (PAS) karena ada beberapa siswa yang tidak mengikuti pelaksanaan PAS pada waktu yang telah ditetapkan dengan alasan yang nampak begitu dibuat-buat. Sampai akhirnya nilai hasil semester mereka penulis rekap. Hasil Penilaian Semester mereka menurun jika dibandingkan dengan hasil penilaian mereka ditingkatan kelas sebelumnya.

Akhirnya melalui wawancara terhadapa beberapa siswa, penulis dapat menarik beberapa hal yang menyebabkan kurangnya antusias siswa dalam proses pembelajaran daring daring di semester I adalah dikarenakan : bosan, jenuh, monoton , mendengarkan penjelasan kemudian diberi latihan. dan susah memahami materi. Sehingga mereka merasa hal tersebut tidak menyenangkan dan sangat membosankan. Mereka menginginkan suasana seperti layaknya pembelajaran tatap muka, saling berebutan menjawab dan bertanya. Itulah sebabnya mengapa pembelajaran daring yang dilakukan bukanlah hal yang dinantikan mereka setiap pagi dan mereka menjadi pasif.

Untuk menguatkan argument penulis atas apa yang disampaikan siswa, penulis juga melakukan wawancara terhadap beberapa orang tua, dan dari wawancara tersebut terungkap bahwa pada saat pembelajaran daring siswa tidak fokus dan kadang sambil tiduran. Malahan ada yang hanya mengaktifkan kelas daring, namun mereka malah pergi dan bermain atau pun kembali tidur di dalam kamar. Ada juga yang mengatakan bahwa siswa kesulitan dalam memahami materi pembelajaran, siswa menjadi malas untuk bangun pagi dan asyik menggunakan ganget sampai larut malam dengan alasan mengerjakan tugas sekolah

Permasalahan yang dihadapi siswa kelas V Firdaus memang komplit mengingat selama pandemi 
covid 19, mereka tidak lagi bisa beraktivitas seperti sebelum pandemi melanda. Semua aktivitas di luar rumah sangat terbatas. Mereka tentu sangat merindukan bisa berkumpul bersama teman dan bermain bersama. Ditambah lagi dengan pembelajaran daring yang menurut mereka membosankan.. Pembelajaran daring yang menurut siswa kelas 5 Firdaus membosankan bisa disebabkan oleh hal-hal sebagai berikut : (1) Materi baru yang disampaikan tidak memiliki kesiapan yang memadai pada siswa sehingga materi itu terasa asing bagi siswa, dan (2) Cara penyampaian guru yang kurang menarik sehingga tidak muncul rasa ingin tahu yang tinggi dari siswa.

Berdasarkan hal-hal tersebut di atas dan dari hasil wawancara terhadap orang tua dan siswa, penulis berinisiatif untuk mengubah strategi pembelajaran daring yang selama ini dilakukan agar proses pembelajarang daring mampu : (1) membuat siswa bisa kembali disiplin dengan memulai aktivitas pagi sesuai dengan ajaran agama, (2) Siswa kembali bersemangat dan aktif mengikuti pembelajaran secara daring, (3) Tertib dalam proses pembelajaran, dan (4) Bijak dalam penggunaan perangkat ganget

Salah satu upaya penulis dalam mengembalikan suasana pembelajaran yang menyenangkan adalah dengan menampilkan gambar-gambar atau videovideo yang menarik yang dapat memancing respon mereka sebagai pengantar awal penjelasan materi. Hal ini dimaksudkan sebagai berikut : (1) Hasil usaha guru agar gambar atau video yang ditampilkan bisa menjadi pengantar dalam memahami materi baru, (2) Gambar atau video yang disajikan bisa dijadikan sebagai respon awal kesiapan siswa dalam memahami materi baru, dan (3) Gambar dan video yang disajikan mampu menarik minat dan motivasi siswa dalam memahami materi baru.

Dari respon yang diberikan siswa berdasarkan hasil pengamatannya terhadap gambar dan video yang disajikan, bisa dijadikan umpan balik kepada siswa agar siswa kelas V Firdaus bisa mengambil nilai-nilai positif dari gambar-gambar/video yang disajikan sehingga mampu meningkatkan rasa syukur terhadap apa yang dianugrahkan Allah SWT terhadap mereka.

Menurut Hari Wibawanto yang merupakan salah satu Tim Pengembang Pendidikan Jarak Jauh Kemenristekdikti (2012 -2019) Kemendikbud (2019

sekarang ) mengatakan bahwa "Kondisi pembelajaran pada masa pandemi covid-19 ini dilakukan sistem pembelajaran daring (dalam jaringan) yang merupakan sistem pembelajaran tanpa tatap muka secara langsung antara guru dan siswa tetapi dilakukan melalui online yang menggunakan jaringan internet. Dengan demikian guru dituntut merancang dan mendesain pembelajaran daring melalui presentasi melalui video, slide presentasi animasi, buku teks, slide presentasi dengan memanfaatkan perangkat atau media daring yang tepat dan sesuai dengan materi yang diajarkan". (Webinar PGSD Prodi PGSD FIP Unimed, 29 Juli 2020)

Berdasarkan hasil penelitiannya, Husmawati menyatakan Pendekatan kontekstual dengan menggunakan media video dalam pembelajaran dapat meningkatkan aktivitas guru dan siswa yang ditunjukkan dari prolehan skor pengamatan terhadap aktivitas guru dalam 3 pertemuan (2016:102.) Hal ini diperkuat oleh penelitian Kadek Merta dkk, Kelas IV Gugus II Kecamatan Abang Kabupaten Karangasem yang (e-journal,2015:7) diperoleh kesimpulan pertama, terdapat perbedaan motivasi berprestasi antara kelompok siswa yang mengikuti pembelajaran dengan menggunakan pendekatan pembelajaran kontekstual berbantuan media visual dengan kelompok siswa yang mengikuti pembelajaran konvensional pada mata pelajaran IPA kelas IV di SD Gugus II, Kecamatan Abang, Kabupaten Karangasem.

Menurut Gagne yang (1986:6) bahwa "Media adalah berbagai jenis komponen dalam lingkungan siswa yang dapat merangsang untuk belajar". Gambar sebagai media pendidikan tentunya mempunyai fungsi yang diharapkan dalam proses belajar mengajar. Dengan alat bantu gambar siswa akan lebih mudah dalam memahami pelajaran yaitu dengan memperlihatkan gambar-gambar dari pada kata-kata.

Kemudian pendapat Hardianti,dkk (2017:125) mengatakan bahwa Media video merupakan salah satu penentu keberhasilan pembelajaran. Melalui media video proses pembelajaran lebih menarik dan menyenangkan. Informasi yang disampaikan secara lisan terkadang tidak dipahami sepenuhnya oleh siswa, terlebih lagi guru kurang cakap dalam memperjelas materi, maka media berperan sebagai alat bantu untuk memperjelas pesan yang disampaikan dalam proses belajar mengajar.

Menurut Johnson (2010:6) mengartikan pembelajaran kontekstual adalah suatu proses pendidikan yang bertujuan membantu siswa melihat makna dalam bahan pelajaran yang mereka pelajari dengan cara menghubungkannya dengan konteks kehidupan mereka sehari-hari, yaitu dengan konteks lingkungan pribadinya, sosialnya, dan budayanya.

Berdasarkan beberapa hasil penelitian dan pendapat ahli , dapat ditarik kesimpulan bahwa penggunaan pendekatan pembelajaran kontekstual berbantuan media gambar dan video untuk memberikan efek yang positif dalam pembelajaran, selain itu, diharapkan juga mampu mengembali kedisplinan dan ketertiban siswa kelas V Firdaus dalam proses kegiatan belajar mengajar dan aktivitas ibadah sehari-hari sehingga mereka bisa mengambil hikmah dari pandemi covid 19 ini karena hasil belajar bukan hanya meliputi aspek kognitif dan psikomotor namun juga dapat mempengaruhi aspek afektif. Seorang siswa perlu memiliki sikap disiplin dengan melakukan latihan untuk memperkuat dirinya sendiri untuk selalu terbiasa bersikap taat terhadap peraturan yang telah ditetapkan. Karakter disiplin bisa dilakukan di rumah maupun di sekolah. Dirumah dilakukan oleh orang tua, sedangkan di sekolah dilakukan oleh guru sebagai fasilitator siswa belajar lebih baik. Oleh karena itu, penting bagi seorang guru untuk memiliki strategi yang tepat yang dapat digunakan untuk menanamkan sikap disiplin tersebut kedalam kehidupan siswa. Disiplin yang tumbuh secara sadar akan membentuk sikap, perilaku, dan tata kehidupan yang teratur yang akan menjadikan siswa sukses tak hanya dalam belajar namun juga dalam lingkungan kehidupannya

Penerapan sikap kedisplinan akan berjalan dengan baik apabila guru, siswa dan semua warga sekolah saling mendukung satu sama lain untuk melaksanakan aturan yang berlaku. Oleh sebab itu perlu dipahami bahwa aturan di sekolah merupakan kumpulan aturan yang dibuat oleh sekolah secara tertulis dan bersifat mengikat untuk semua warga sekolah. Setiap aturan yang dibuat pasti akan 
mengikat dan bagi yang melanggar aturan tentulah akan diberi sanksi. Hal ini supaya proses belajar mengajar dapat berjalan dengan lancar dan prestasi siswa menjadi maksimal.

Menurut Gagne (dalam Kokom Komalasari,2010,2) "Belajar sebagai sutau proses perubahan tingkah laku yang meliputi perubahan kecendrungan manusia seperti sikap, minat atau nilai dan perubahan kemampuannya yakni peningkatan kemampuan untuk melakukan berbagai jenis performance(kinerja)". Sedangkan menurut Sunaryo (dalam Kokom Komalasari,2010;2) "Belajar merupakan suatu kegiatan dimana seseorang membuat atau menghasilkan suatu perubahan perilkau yang ada pada dirinya dalam pengetahuan, sikap dan keterampilan".

Dengan demikian dapat disimpulkan belajar adalah perubahan tingkah laku pada individuindividu yang belajar. Perubahan itu tidak hanya berkaitan dengan penambahan ilmu pengetahuan, tetapi juga berbentuk kecakapan, minat, watak, penyesuaian diri. Jadi dapat dikatakan bahwa belajar itu sebagai rangkaian kegiatan jiwa raga yang menuju perkembangan pribadi manusia seutuhnya

Tujuan penulisan ini adalah untuk memberikan gambaran informasi tentang persiapan, pelaksanaan dan kendala apa saja yang dihadapi dalam mengembangkan sikap kedisplinan dan ketertiban dalam pembelajaran daring melalui media Gavi berbasis kontekstual pada siswa kelas V Firdaus.

\section{METODE PENELITIAN}

Untuk memecahkan permasalahan yang telah dipaparkan di pendahuluan, maka ada beberapa langkah yang harus penulis lakukan yaitu : (1) Analisis situasi, (2)Wawancara dan mencari penyebabnya, (3)Menentukan beberapa alternatif yang relevan, (4)Merancang RPP yang memuat video dan gambar yang kontekstual, (5)Pelaksanaan proses pembelajaran, (6) Melakukan Observasi dari hasil pelaksanaan , (7)Refleksi, (8) Menindaklanjuti.

\section{HASIL DAN PEMBAHASAN PENELITIAN}

Sebelum melakukan tahapan pelaksanaan, penulis terlebih dahulu sudah melakukan analisis dan melakukan wawancara terhadap beberapa siswa dan perwakilan orang tua. Berdasarkan hasil analisis dan wawancara, penulis menemukan alternatif bahwa dalam proses pelaksanaan pembelajaran, penulis harus menggunakan media yang gambar dan video yang menarik buat menarik minat siswa dalam proses pembelajaran. Dimana gambar dan video tersebut mampu memberikan pesan moral kepada siswa akan pentingnya sikap kedisplinan dan ketertiban dalam kehidupan sehari-hari. Selanjutnya di tahap mempersiapkan pelaksanaan, penulis terlebih dahulu membuat rancangan pembelajaran yang akan memuat gambar dan video yang kontestual. Rancangan pembelajaran di buat dalam dua versi yaitu: (1) RPP yang dibuat sesuai versi RPP yang telah disosialisasikan oleh YPI Al Azhar; (2) RPP yang versi PPG Prajabatan tahun 2020 yang memuat kegiatan perhari pelaksanaan. Rancangan pembelajaran tersebut juga divalidasi secara online oleh salah satu dosen LPTK (Lembaga Pendidikan Tenaga Kependidikan) Universitas Tanjungpura.

Setelah rancangan pembelajaran di validasi, penulis menyiapkan media pembelajaran dalam bentuk power point tempale yang akan di share pada saat proses pembelajaran. Gambar dan video yang akan disajikan adalah gambar dan video yang sesuai dengan materi, memiliki pesan edukatif dan sesuai dengan usia siswa. Penulis mencari gambar dan video tersebut dari google dan youtube. Setelah menemukan gambar dan video yang sesuai, khusus untuk video, ada beberapa bagian yang di edit oleh penulis dikarena ada video yang terlalu panjang durasinya. Media gambar dan video yang akan disajikan adalah gambar dan video yang dapat memberikan pesan moral tentang adab kedisplinan dan ketertiban dalam belajar dan kehidupan seharihari. Setelah menyiapkan media pembelajaran, penulis menyiapkan soal evaluasi dalam bentuk google form, dimana soal evaluasi tersebut diberikan selain untuk melihat kemampuan kognitif siswa juga mau melihat tingkat kedisplinan siswa dalam mengerjakan dan mengumpulkan tugas harian.

Pada tahap pelaksanaan, di awali dengan mengshare link zoom di group WA kelas 15 menit sebelum kegiatan dimulai. Hal ini dimaksudkan untuk mengecek kesiapan siswa. Di 5 menit sebelum kegiatan belajar mengajar dimulai sudah bergabung sekitar 22 siswa. Sehingga kegiatan pembelajaran bisa dilaksanakan tepat pada pukul dan siswa yang bergabung berjumlah 25 siswa. Guru memulai kegiatan dengan mengucapkan salam dan meminta salah satu siswa untuk memimpin pembacaan doa. Setelah selesai membaca doa, guru mengecek kehadiran siswa dan mengecek kegiatan ibadah siswa di pagi hari. Kemudian guru melakukan apersepsi untuk mengingatkan kembali siswa tentang materi sebelumnya sehingga guru lebih mudah untuk melanjutkan ke materi selanjutnya.

Setelah melakukan tanya jawab dalam kegiatan apersepsi, guru menyampaikan tujuan pembelajaran dan memberikan motivasi kepada siswa. Dalam hal ini, guru menampilkan sebuah video singkat tentang kisah sebuah jarum jam. Dimana dalam kisah ini dapat ditarik kesimpulan bahwa kita harus yakin pada kemampuan diri kita sendiri dalam menciptakn suatu perubahan dan menciptakan suatu hal yang besar. Walaupun hal tersebut kita rasakan sulit. Dalam hal ini, guru juga menyampaikan bahwa untuk memulai aktivitas pagi lebih awalnya berat, untuk displin melaksanakan shalat 5 waktu tepat waktu juga berat, namun jika kita konsisten dan melakukannya secara terus menerus, maka hal tersebut akan menjadi mudah. Setelah memberikan motivasi, proses pembelajaran masuk tahap kegiatan inti dimana guru menyampaikan materi dengan beberapa tahapan: (1) Guru melakukan tanya jawab dengan siswa bagaimana cara mencari informasi dari sebuah teks eksplanasi dan siswa memberikan beberapa tanggapan; (2) Guru membudayakan kegiatan literasi dengan meminta siswa untuk membaca sebuah teks eksplanasi secara bergiliran; (3) Guru memberikan tugas kepada siswa untuk membuat kalimat tanya guna mencari informasi yang terdapat dalam teks dan siswa memberi respon yang baik dengan bergantian membuat kalimat Tanya; (4) Guru kembali melakukan tanya jawab dari gambar-gambar yang disajikan guna membangkitkan motivasi dan minat belajar siswa dan sebagai alat komunikasi dalam menyampaikan pesan yang lebih konkret kepada siswa, sehingga lebih mudah dipahami dan dipelajari dan siswa sangat aktif dalam memberikan jawaban serta ada juga siswa yang menyebutkan pengalamannya sendiri; (5) Guru menampilkan sebuah video yang berhubungan 
dengan materi, yaitu video tentang Asal Usul Termos; (6) Setelah menyaksikan video, guru kembali melakukan tanya jawab yang berhubungan dengan ketertiban dalam meletakkan benda dan siswa merespon dengan menyebutkan hal-hal yang mungkin bisa saja terjadi.
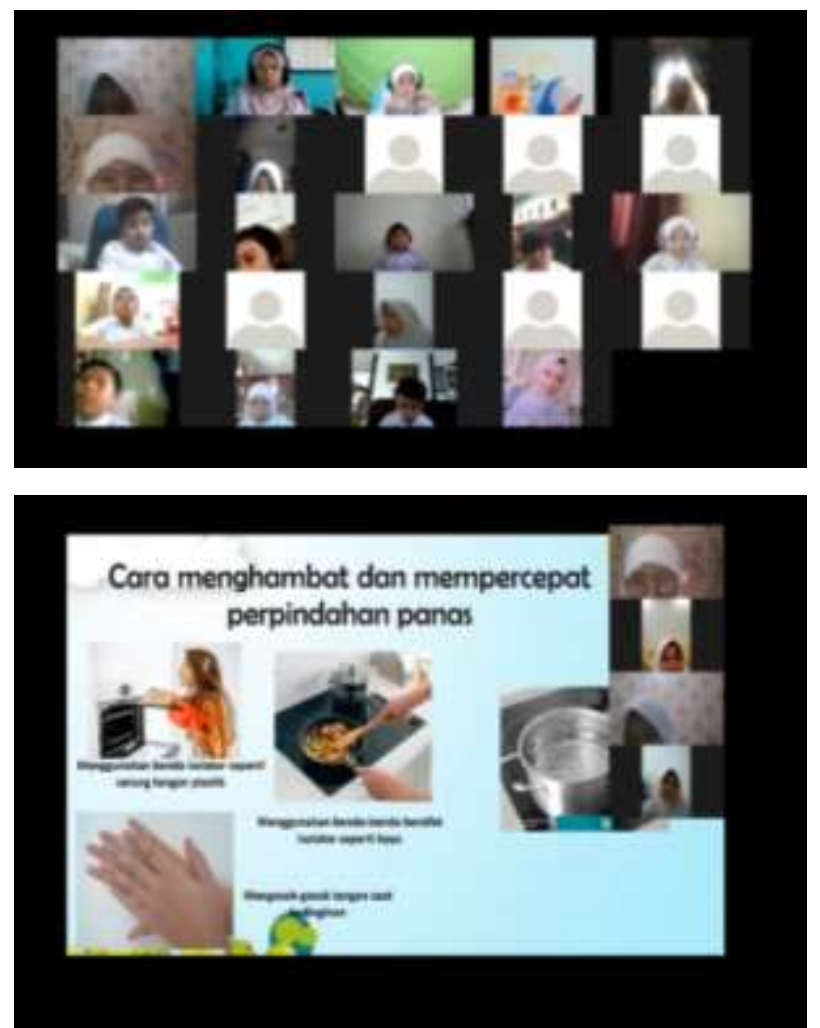

Setelah kegiatan inti selesai, guru memasuki tahapan kegiatan penutup, dimana dalam kegiatan penutup guru melakukan beberapa hal: (1) Guru menanyakan dari tampilan video yang disajikan, mana video yang paling siswa sukai. Dari tanggapan siswa dapat diketahui bahwa siswa menyukai kedua video yang ditampilkan; (2) Guru menanyakan apakah gambar yang ditampilkan menarik buat mereka, dan dari respon siswa, mereka tertarik dengan gambar terutama salah satu gambar cover buku. Sehingga mereka tertarik untuk membaca isi buku tersebut; (3) Guru menanyakan, apakah sebelumnya siswa sudah pernah menyaksikan videovideo yang ditampilkan?. Siswa memberi tanggapan bahwa video-video tersebut belum pernah mereka tonton sebelumnya; (4) Guru memberikan pemahaman dari gambar dan video yang dsajikan sangat berhubungan dengan kehidupan mereka sehari-hari; (5) Guru mengajak siswa untuk menyimpulkan pembelajaran hari ini; (6) Guru memberikan pesan moral yang berhubungan dengan kedisplinan dan tata tertib; (7) Guru mengaitkan kedisplinan bangun pagi dengan hadist yang diriwayatkan oleh: HR. Bukhari no. 1142 dan Muslim no. 776 dan H.R. Imam Ahmad Dan AlBaihaqi.

Selama proses pelaksanaan pembelajaran, penuls menghadapi beberapa kendala baik permasalahan teknis maupun permasalahan proses pelaksanaan. Di permasalahan teknis yang dialami oleh penulis adalah adanya gangguan sinyal dari tiap provider yang membuat suara yang diterima oleh siswa kurang jelas dan putus-putus, selain itu masalah kepemilikan gawai sehingga link yang dikirim telat sampai ke siswa.

Untuk di permasalahan proses pelaksanaan, mengingat ada 29 siswa di dalam kelas, tentu saja setiap siswa memiliki karakteristik masing-masing yang tidak bisa kita samakan perlakukannya dengan siswa lain. Sehingga membuat guru harus mampu memiliki strategi agar tidak menganggu proes pelaksanaan pembelajaran. Selain itu, dikarenakan proses pembelajaran tersebut dilakukan melalui online maka guru sulit untuk mengontrol ketertiban siswa untuk tetp bertahan di dalam proses pembelajaran daring. Hal ini terlihat pada saat kegiatan penutup, jumlah siswa yang bergabung sudah berkurang. Permasalahan tersebut juga dikarenakan lemahnya sanksi yang diberikan kepada siswa yang tidak disiplin dalam proses pembelajaran online.

\section{SIMPULAN DAN SARAN \\ Simpulan}

Berdasarkan hasil observasi dan pelaksanaan yang telah penulis lakukan dan di paparkan maka penulis memberikan kesimpulan sebagai berikut : (1) Pada tahap persiapan, penulis membuat RPP dan menyiapkan media pembelajaran yang memuat gambar dan video yang edukatif dan kontekstual. Ditahap ini penulis mengalami kesulitan dalam hal mencari video yang sesuai dengan materi dan memuat pesan moral yang mampu membuat siswa memahami materi. Dalam tahap persiapan ini, yang perlu diperhatikan adalah bagaimana merancang RPP yang memuat hal-hal yang mampu menyeimbangkan kemampuan kognitif, afektif dan psikomotorik siswa. (2) Pada tahap pelaksanaan, penulis dominan menampilkan gambar dan video. Di kegiatan pembukaan, ketika memberi motivasi, guru menyajikan video tentang kisah sebuah jarum jam dan di kegiatan inti, guru menyajikan sebuah video tentang asal usul termos. Hal paling baik yang terjadi pada proses pelaksanaan adalah saat siswa mampu mengkomunikasikan gambar yang disajikan. Sedangkan hal yang paling sulit dicapai adalah melatih dan menerapkan sikap tertib pada saat proses pembelajaran. Karena masih terdapat siswa yang menulis chat, yang mematikan kamera dan mainmain pada saat proses pembelajaran. (3) Kendala yang dihadapi guru dalam membangun karakter kedisplinan dan ketertiban siswa dalam proses pembelajaran daring adalah permasalahan sinyal yang tidak stabil sehingga membuat suara guru terputus-putus dan sulitnya mengontrol kedisplinan dan ketertiban siswa pada saat proses pembelajaran.

\section{Saran}

Berdasarkan kesimpulan, maka dapat dikemukakan saran sebagai berikut yaitu (1) Guru kelas berkerjasama dengan seluruh rekan guru khususnya guru agama agar pembelajaran adab lebih dimaksimal lagi proses pelaksanaannya dengan mendisplinan kegiatan ibadah harian khususnya dalam hal pengkontrolan kegiatan. (2) Sekolah diharapkan dapat memenuhi sarana dan prasarana untuk menunjang proses pembelajaran. Sekolah diharapkan dapat ikut serta dalam memberikan perhatian dan terus mengawasi keadaan khususnya dalam pembinaan pembentukan karakter siswa.

\section{DAFTAR PUSTAKA}

Hardianti dan Asri WK. (2017) Keefektifan Penggunaan Media Video dalam Keterampilan Menulis Karangan Sederhana Bahasa Jerman Siswa Kelas XII IPA SMA Negeri 11 Makassar , Jurnal Pendidikan Bahasa Asing dan Sastra Volume 1 No.2 Agustus 2017 .126. 
Husmawati (2016) Peningkatan Hasil belajar Siswa Melalui Pendekatan Kontekstual Dengan menggunakan Media Video Pada Materi Fluida Statis di SMA Negeri 1 Leumbah Seulawah. (Skripsi,Universitas .....,2016)

Kadek Merta,Wayan, Suastra.((2015).Pengaruh Pendekatan Pembelajaran Kontekstual Berbantuan Media Visual Terhadap Motivasi Berprestasi dan Hasil Belajar IPA Pada siswa Kelas IV Gugus II Kecamatan Abang Kabupaten Karangasem, e- Journal Program Pascasarjana Universitas Pendidikan Ganesha Program Studi Pendidikan Dasar (Volume 5 Tahun 2015), 7.
Komalasari, Kokom (2010) Pembelajaran Kontekstual : Konsep dan Aplikasi. Bandung:PT. Refika Aditama

Prodi PGSD Unimed. (2020) Kiat Pembelajaran Anak Dalam Adaptasi Kebiasan Baru. Diakses pada $10 \quad$ Agustus 2020 dari https://pgsd.unimed.ac.id/?s=Kiat+Pembelajara n+Anak+Dalam+Adaptasi+Kebiasan+Baru

S. Sadiman,Arief dkk. (1986) Media Pendidikan. Jakarta:PT .Raja Grafindo Persada

Sukiman, (2000) Pengembangan Media Pembelajaran .Yogyakarta:PT Pustaka Insan Madani 